\title{
Review on Comparative Study of Steel and AluminiumAlloy Roof Truss
}

\author{
Patil N. S. ${ }^{1}$, Jawalkar G.C. $^{2}$ \\ ${ }^{1}$ ME Student, Civil Engineering Department, N.B.Navale Sinhgad College of Engineering, Kegaon, Solapur, India \\ ${ }^{2}$ Assistant Professor, Civil Engineering Department, N.B.Navale Sinhgad College of Engineering, Kegaon, Solapur, India
}

\begin{abstract}
The aluminium element was discovered 200 years ago. After an initial period of technological development, aluminium alloys were used in many structural applications, including the civil engineering field. Aluminium is the second most widely specified metal in building after steel, and is used in all sectors from commercial building to domestic dwelling. This paper contains complete overview of use of aluminium in roof truss construction. How it is beneficial in modern roof truss construction. This paper also contains the properties, advantages and results.
\end{abstract}

Keywords: Aluminium alloy, steel, unit weight, comparison, angle sections

\section{Introduction}

A comparison between the two metallic materials, aluminium and steel, is necessary in order to emphasize the specific characteristics and the advantages, as well as sometimes the disadvantages, of aluminium alloys as structural material. Pure aluminium dose not have yield strength and tensile strength. However the addition of alloying elements like manganese, silicon, copper and magnesium can increase the strength properties of aluminium. This comparison can lead to identify the design criteria which must be followed in order to make the use of aluminium alloys friendly and actually competitive with steel in the range of structural design There are many reasons for the selection of a material for structural applications, but the determinant issue is that the product must be affordable, i.e. its cost must be acceptable to the customer. Generally, aluminium is attractive in many applications, because of a favorable life-cycle cost, which is given by the sum of the initial cost of the finished product, the cost of operating or maintaining the product over its life and the cost of disposing of or recycling it after its useful life. In addition, aluminium has sustained and increased its use in many fields.

Aluminium and steel are different materials but design problems usually are similar. Aluminium differs from steel in its physical properties (low mass weight, stiffness and linear expansion) and in its mechanical properties (strength and elongation), the latter as a result of alloy hardening. A designer should make use of the advantages of aluminium in particular its light weight, extrudability and corrosion resistance and find adequate solutions for the disadvantages such as its low stiffness, resulting in stability being a more predominant design aspect, and its lesser fatigue and fire resistance behavior, when compared to steel.

\subsection{Design Philosophies (Working stress method)}

The aim of analysis and design of aluminium structure and steel structure is to compare the strength, and unit weight. The properties of aluminium alloy are near about same as that of steel.
So that the structure being designed will perform satisfactorily during its intended life. With an appropriate degree of safety the structure should

- Sustain all loads expected on it.

- Sustain deformations during and after construction.

- Structure should be stable and have alternate load paths to prevent overall collapse under accidental loading.

\subsection{Configuration of Truss}

\subsubsection{Pitched Roof Trusses}

Most common types of roof trusses are pitched roof trusses wherein the top chord is provided with a slope in order to facilitate natural drainage of rainwater and clearance of dust/snow accumulation. These trusses have a greater depth at the mid-span. Due to this even though the overall bending effect is larger at mid-span, the chord member and web member stresses are smaller closer to the mid-span and larger closer to the supports.

\subsubsection{Analysis of Aluminium and Steel Roof Trusses: -}

Aluminium and steel structure are analysed on the basis of their unit weights. In the analysis I was considered the number of forces acting on the structure such as dead load, live load, and wind loads with three load combinations $\{1 .[(\mathrm{DL}+\mathrm{LL}) \times 1.5], 2$. [(DL+LL+WL) $\times 1.2], 3 .[(\mathrm{DL}+\mathrm{WL}) \times$ $1.5]\}$.

\subsection{Design Problem}

In this work, a typical warehouse truss problem has been considered for analysis and design by working stress method of both aluminium and steel roof truss. Span of truss is taken as $10 \mathrm{~m}, 14 \mathrm{~m}, 17 \mathrm{~m}$, and $20 \mathrm{~m}$ with spacing of truss in between $4 \mathrm{~m}$ to be built near Pune. Class of Building assumed as class 1 and terrain category 3 . Width of Building: $10 \mathrm{~m}, 14 \mathrm{~m}, 17 \mathrm{~m}$, and $20 \mathrm{~m}$ Height of eve level is considered as $10 \mathrm{~m}$. Permeability of structure is assumed as normal with span of Purlins taken as $1.425 \mathrm{~m}$. Rise of truss is $1 / 4$ of span. Assume the weight of purlin. Type of truss is simple Pratt truss. 


\section{International Journal of Science and Research (IJSR) \\ ISSN (Online): 2319-7064 \\ Index Copernicus Value (2015): 78.96 | Impact Factor (2015): 6.391}

\subsubsection{Loading}

For analyzing the roof truss I was considered the following loads,

1) Dead load:- Various types of Dead loads acting on roof truss such as weight of Sheet which is used for covering, self weight of all the members either steel members or aluminium members, weight of fixtures, self weight of purlins, etc. All the unit weightsare taken from IS 875 (Part-1) and IS 8147-1976.

a) Consider unit weight of AC sheet is $0.13 \mathrm{KN} / \mathrm{m}^{2}$.

b) Consider unit weight of purlin for aluminium and steel are $30 \mathrm{~N} / \mathrm{m}$ and $100 \mathrm{~N} / \mathrm{m}$ respectively.

c) Consider unit weight of fixtures for both materials is $0.05 \mathrm{KN} / \mathrm{m}^{2}$.

d) Consider unit weight of rafter bracing for aluminium and steel are $0.05 \mathrm{KN} / \mathrm{m}^{2}$ and $0.1 \mathrm{KN} / \mathrm{m}^{2}$ respectively.

2) Live load: - Live load is taken from IS 875 (part-2).

3) Wind load: - Wind load is taken from IS 875 (part-3).

\subsubsection{Selection of aluminium alloy}

The four aluminium alloy most commonly used in general and structural engineering.
1) Principal alloy 64430 (H30):- For general use, particularly in bolted or riveted frame structures this alloy is the normal choice on the ground of strength, durability and economy. It is supplied as plates, extruded sections (both solid and hollow), sheet, tube and forgings. It is weldable but with considerable reduction of strength near the welds.

2) Principal alloy 65032 (H20):- This alloy is the medium strength alloy and has similar applications as 64430 (H30) in general structures.

3) Principal alloy 63400 (H9):- This alloy combines moderate strength with high durability and good surface finish that response well to anodizing. Like 64430 (H30) its also losses parts of its strength on welding.

4) Principal alloy 54300 (N8):- This alloy is highly durable and strong for weldable structures and plate work. It shows less reduction in strength after welding.

For analysis and design of aluminium roof truss we are using first alloy 64430 (H30) and analyzing the same in staad pro and we got following results.

Table 1: Panel point loads on truss

\begin{tabular}{|c|c|c|c|c|c|c|}
\hline \multirow[t]{2}{*}{ Span in $\mathrm{m}$} & \multirow[t]{2}{*}{ Load } & \multirow[t]{2}{*}{ Number of panel point } & \multicolumn{2}{|c|}{$\begin{array}{l}\text { Panel Point Load in KNFor } \\
\text { Aluminium roof truss }\end{array}$} & \multicolumn{2}{|c|}{$\begin{array}{c}\text { Panel Point Load in } \\
\text { KN For Steel roof truss }\end{array}$} \\
\hline & & & Intermediate & End & Intermediate & End \\
\hline \multirow[t]{3}{*}{$10 \mathrm{~m}$} & Dead load & \multirow[t]{3}{*}{8} & 1.697 & 0.848 & 2.407 & 1.203 \\
\hline & Live load & & 1.395 & 0.697 & 1.395 & 0.697 \\
\hline & Wind load & & 4.220 & 2.110 & 4.220 & 2.110 \\
\hline \multirow[t]{3}{*}{$14 \mathrm{~m}$} & Dead load & \multirow[t]{3}{*}{12} & 1.696 & 0.848 & 2.358 & 1.179 \\
\hline & Live load & & 1.302 & 0.651 & 1.302 & 0.651 \\
\hline & Wind load & & 3.940 & 1.970 & 3.940 & 1.970 \\
\hline \multirow[t]{3}{*}{$17 \mathrm{~m}$} & Dead load & \multirow[t]{3}{*}{14} & 1.934 & 0.967 & 2.603 & 1.301 \\
\hline & Live load & & 1.355 & 0.677 & 1.355 & 0.677 \\
\hline & Wind load & & 4.101 & 2.051 & 4.101 & 2.051 \\
\hline \multirow[t]{3}{*}{$20 \mathrm{~m}$} & Dead load & \multirow[t]{3}{*}{16} & 2.036 & 1.018 & 2.71 & 1.354 \\
\hline & Live load & & 1.395 & 0.697 & 1.395 & 0.697 \\
\hline & Wind load & & 4.22 & 2.11 & 4.22 & 2.11 \\
\hline
\end{tabular}

Table 2: Design forces of truss members by using staad pro

\begin{tabular}{|c|c|c|c|c|c|}
\hline \multirow{2}{*}{$\begin{array}{c}\text { Span in } \\
\mathrm{m}\end{array}$} & \multirow{2}{*}{ Member } & \multicolumn{2}{|c|}{ Design forces (Aluminium) in KN } & \multicolumn{2}{c|}{ Design forces (Steel) in KN } \\
\cline { 3 - 6 } 10 & & Tension & Compression & Tension & Compression \\
\hline \multirow{4}{*}{10} & Principle Rafter & 27.5625 & 36.303 & 19.2135 & 44.634 \\
\cline { 2 - 6 } & Tie Member & 32.466 & 20.394 & 39.921 & 12.939 \\
\cline { 2 - 6 } & Inclined Strut & 10.275 & 10.0425 & 12.6315 & 7.677 \\
\cline { 2 - 6 } & Vertical Strut & 8.9445 & 9.1545 & 6.8385 & 11.2545 \\
\hline \multirow{4}{*}{14} & Principle Rafter & 36.6885 & 55.3155 & 24.4695 & 67.5285 \\
\cline { 2 - 6 } & Tie Member & 49.467 & 28.842 & 60.39 & 17.919 \\
\cline { 2 - 6 } & Inclined Strut & 13.281 & 12 & 16.2135 & 9.0675 \\
\cline { 2 - 6 } & Vertical Strut & 11.2755 & 12.48 & 8.52 & 15.2355 \\
\hline & Principle Rafter & 40.8855 & 71.715 & 26.3055 & 86.2905 \\
\cline { 2 - 6 } & Tie Member & 64.1355 & 32.439 & 77.181 & 19.3935 \\
\cline { 2 - 6 } & Inclined Strut & 17.2695 & 13.917 & 20.7825 & 10.404 \\
\cline { 2 - 6 } & Vertical Strut & 13.3305 & 16.5405 & 9.966 & 19.905 \\
\hline 20 & Principle Rafter & 46.8855 & 86.3085 & 29.9295 & 103.2645 \\
\hline & Tie Member & 77.1975 & 37.6905 & 92.3625 & 22.5255 \\
\hline & Inclined Strut & 20.8845 & 16.323 & 24.987 & 13.5 \\
\hline & Vertical Strut & 15.8175 & 20.238 & 11.841 & 24.2145 \\
\hline
\end{tabular}




\section{International Journal of Science and Research (IJSR) \\ ISSN (Online): 2319-7064}

Index Copernicus Value (2015): 78.96 | Impact Factor (2015): 6.391

Table 3: Comparison of Unit Weight and sections of Aluminium and Steel

\begin{tabular}{|c|c|c|c|c|c|}
\hline \multirow[t]{2}{*}{ Span in $\mathrm{m}$} & \multirow[t]{2}{*}{ Member } & \multicolumn{2}{|c|}{ Aluminum Truss Member } & \multicolumn{2}{|c|}{ Steel Truss Member } \\
\hline & & Section & $\begin{array}{c}\text { Unit Weight in } \\
\mathrm{KN} / \mathrm{m}\end{array}$ & Section & $\begin{array}{c}\text { Unit Weight in } \\
\mathrm{KN} / \mathrm{m}\end{array}$ \\
\hline \multirow[t]{4}{*}{10} & Principle Rafter & $\begin{array}{c}\text { ALE } \\
50 \times 50 \times 5\end{array}$ & 1.9 & $\begin{array}{c}\text { 2ISA } \\
45 \times 45 \times 4\end{array}$ & 2.7 \\
\hline & Tie Member & $\begin{array}{c}2 \text { ALE } \\
45 \times 45 \times 4\end{array}$ & 0.95 & $\begin{array}{c}\text { 2ISA } \\
40 \times 40 \times 4\end{array}$ & 2.4 \\
\hline & Inclined Strut & $\begin{array}{c}\text { ALE } \\
60 \times 60 \times 4 \\
\end{array}$ & 1.28 & $\begin{array}{c}\text { ISA } \\
35 \times 35 \times 5 \\
\end{array}$ & 2.6 \\
\hline & Vertical Strut & $\begin{array}{c}\text { ALE } \\
60 \times 60 \times 4\end{array}$ & 1.28 & $\begin{array}{c}\text { ISA } \\
40 \times 40 \times 6\end{array}$ & 3.5 \\
\hline \multirow[t]{4}{*}{14} & Principle Rafter & $\begin{array}{c}2 \text { ALE } \\
60 \times 60 \times 4\end{array}$ & 1.28 & $\begin{array}{c}\text { 2ISA } \\
45 \times 45 \times 6 \\
\end{array}$ & 4 \\
\hline & Tie Member & $\begin{array}{c}2 \mathrm{ALE} \\
50 \times 50 \times 4\end{array}$ & 1.06 & $\begin{array}{c}\text { 2ISA } \\
45 \times 45 \times 5 \\
\end{array}$ & 3.4 \\
\hline & Inclined Strut & $\begin{array}{c}\text { ALE } \\
60 \times 60 \times 4 \\
\end{array}$ & 1.28 & $\begin{array}{c}\text { ISA } \\
35 \times 35 \times 6 \\
\end{array}$ & 3 \\
\hline & Vertical Strut & $\begin{array}{c}\text { ALE } \\
60 \times 60 \times 4 \\
\end{array}$ & 1.28 & $\begin{array}{c}\text { ISA } \\
45 \times 45 \times 5 \\
\end{array}$ & 3.4 \\
\hline \multirow[t]{4}{*}{17} & Principle Rafter & $\begin{array}{c}2 \mathrm{ALE} \\
60 \times 60 \times 5 \\
\end{array}$ & 1.58 & $\begin{array}{c}\text { 2ISA } \\
50 \times 50 \times 6 \\
\end{array}$ & 4.5 \\
\hline & Tie Member & $\begin{array}{c}2 \text { ALE } \\
60 \times 60 \times 4 \\
\end{array}$ & 1.28 & $\begin{array}{c}\text { 2ISA } \\
50 \times 50 \times 6 \\
\end{array}$ & 4.5 \\
\hline & Inclined Strut & $\begin{array}{c}\text { ALE } \\
60 \times 60 \times 5 \\
\end{array}$ & 1.58 & $\begin{array}{c}\text { ISA } \\
45 \times 45 \times 4 \\
\end{array}$ & 2.7 \\
\hline & Vertical Strut & $\begin{array}{c}\text { ALE } \\
60 \times 60 \times 5\end{array}$ & 1.58 & $\begin{array}{c}\text { ISA } \\
45 \times 45 \times 6\end{array}$ & 4 \\
\hline \multirow[t]{4}{*}{20} & $\begin{array}{c}\text { Principle } \\
\text { Rafter } \\
\end{array}$ & $\begin{array}{c}2 \text { ALE } \\
60 \times 60 \times 6 \\
\end{array}$ & 1.88 & $\begin{array}{c}\text { 2ISA } \\
55 \times 55 \times 6\end{array}$ & 4.9 \\
\hline & Tie Member & $\begin{array}{c}\text { ALE } \\
50 \times 50 \times 6\end{array}$ & 1.54 & $\begin{array}{c}\text { 2ISA } \\
55 \times 55 \times 6\end{array}$ & 4.9 \\
\hline & Inclined Strut & $\begin{array}{c}\text { ALE } \\
60 \times 60 \times 6 \\
\end{array}$ & 1.88 & $\begin{array}{c}\text { ISA } \\
45 \times 45 \times 5 \\
\end{array}$ & 3.4 \\
\hline & Vertical Strut & $\begin{array}{c}\text { ALE } \\
70 \times 70 \times 5 \\
\end{array}$ & 1.86 & $\begin{array}{c}\text { ISA } \\
50 \times 50 \times 6 \\
\end{array}$ & 4.5 \\
\hline
\end{tabular}

\section{Review of Literature}

Stefania Arangio, Chiara Crosti, Marco Zampetti:-

In this paper some specific aspects related to the design of aluminium structures for the entertainment industry have been presented. The structural features of aluminium elements depend on both the mechanical properties of the material and the temporary use of the structures. In the early days trusses for the entertainment industry were often fabricated.

R. Gitter (2008) "Design of Aluminium Structures: Selection Of Structural Alloys":

State that, the main reason for the use of aluminium in structural engineering is still its good corrosion behavior. No coating is necessary under most atmospheric conditions. And the costs and environmental problems which exist when renewing organic coatings are still underestimated. We have many structural applications, where, due to the functionality given by the use of extruded sections, the structure is economically competitive.

Federico M. Mazzolani (2006) "Structural Applications of Aluminium in Civil Engineering":-

States that, the success of aluminium alloys as constructional material and the possibility of a competition with steel are based on some prerequisites which are connected to the physical properties, the production process and the technological features.
By Prof. Madhuri K. Rathi, Mr.Ajinkya K. Patil:-

States that, Aluminium, while it has a relatively high initial energy cost, offers unparalleled manufacturing flexibility, the broadest ranges of finishes, an excellent strength-toweight ratio, and unlimited recyclables and has a far better environmental profile than many specifiers believes. Above all, it offers architects the most elegant and satisfying design solutions. For many contemporary designers there are simply no alternative to Aluminium the form dictates the material and the material facilitates the form. This fact alone will ensure the continued growth of Aluminium in construction.

\section{Conclusion}

On the basisof study of steel roof truss and aluminium alloyroof truss mainly we conclude that all the members of aluminium alloy roof trusses are light weight compare to steel roof trusses for different spans and we observed that material consumption is more in aluminium roof trusses. Aluminium alloy roof truss can also suitable where heavy rainfall areas because aluminium is corrosion less so durability of truss may be increases. 


\section{Acknowledgement}

The review study describe in this paper is a part of M.E research work at Solapur University, under the guidance of Prof. G.C. Jawalkar.

\section{References}

[1] Mazzolani, F.M. "Structural use of aluminium alloys in civil engineering" 2004

[2] Talat lecture 1501 aluminium physical properties, characteristics and alloys

[3] Mazzolani, F.M. and Frey, F.: Buckling behavior of aluminium alloy extruded members, Proceedings of the 2nd International Colloquium on Stability of Steel Structures, Liége. (1977)

[4] Mazzolani, F.M. (1981a): European Recommendations for Aluminium Alloy Structures and their comparison with National Standards, Proceedings of the 7th Int. Light Metal Congress, Vienna.(1981a)

[5] Aluminium design and construction, john Dwight, ( MSc, FI Struct E) Former reader in structural engineering, university of Cambridge, nad fellow of magdalene college, Cambridge

[6] IS 800-1984 Indian standard code of practice for general construction in steel.

[7] IS 8147-1976 Indian standard code of practice for use of aluminium alloy in structures

\section{Author Profile}

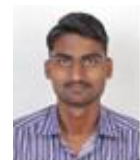

Mr. Patil Nikhil S. received B.E. in Civil Engineering from BIGCE, Solapur (2013) and pursuing M.E. degree in Civil Engineering from NBNSCO, Solapur.

Prof. Jawalkar Ganesh C.B.E. (Civil). M.E. completed from Walchand Institute of Technology Solapur. He is working as Assistant Professor at N.B.Navale Sinhgad College of Engineering, solapur. He has got 16 year of Total Experience. 